\title{
PENERAPAN MODEL EDUKATIF BERBASIS PENDIDIKAN JASMANI UNTUK ANAK USIA 8-12 TAHUN
}

\author{
Raihan Nanda Dwitama ${ }^{1}$, Naufal Hiruchi ${ }^{2}$, M. Fauzan Kamil ${ }^{3}$ \\ 1,2,3Jurusan Ilmu Komunikasi Fakultas Ilmu Sosial Universitas Negeri Jakarta \\ Jln. Rawamangun Muka, Kota Jakarta Timur \\ 1e-mail: fitforkid,id@gmail.com
}

\begin{abstract}
Abstrak
Penelitian ini bertujuan untuk mengetahui proses penerapan model edukatif berbasis pendidikan jasmani untuk anak usia dini pada siswa Sekolah Sepak Bola (SSB) Garuda Indonesia di Kalibata. Metodologi penelitian yang digunakan adalah kualitatif. Teknik pengumpulan data menggunakan observasi dan wawancara mendalam. Informan dalam penelitian ini adalah murid yang belajar pada SSB Garuda Indonesia di Kalibata yang berjumlah 6 anak. Hasil penelitian menunjukkan bahwa informan yang belajar di Sekolah Sepak Bola Garuda Indonesia sudah melakukan penerapan model edukatif berbasis jasmani untuk_membantu mengontrol emosi dalam melakukan kerjasama tim dan juga mengembangkan emosi mereka. Dengan demikian, penerapan model edukatif berbasis jasmani telah dilaksanakan dengan baik di SSB Garuda Indonesia pada anak 8-12 tahun.
\end{abstract}

Kata Kunci: Olahraga, pendidikan jasmani, kesehatan

\begin{abstract}
This research aims to determine the process of applying a physical education based educational model for early childhood students in the Garuda Indonesia Football School (SSB) in Kalibata. The research methodology used is qualitative. Data collection techniques using deep observation and interviews. The informant in the study was a student who studied at the SSB Garuda Indonesia in Kalibata which amounted to 6 children. The results showed that the informant studying at the Garuda Indonesia Football School has been implementing a physical-based educative model to help control emotions in teamwork and also to develop their emotions. Thus, the application of physical based educative Model has been implemented well in SSB Garuda Indonesia in children 8-12 years.
\end{abstract}

Keywords: Sports, physical education, health

\section{PENDAHULUAN}

Pendidikan jasmani adalah bagian dari pendidikan nasional yang bertujuan untuk mengembangkan kemampuan peserta didik melalui aktivitas jasmani. Karena itu pendidikan jasmani adalah pelajaran wajib bagi setiap peserta didik di semua jenjang pendidikan.

Pendidikan jasmani merupakan suatu proses pembelajaran melalui aktivitas jasmani yang didesain untuk meningkatkan kebugaran jasmani mengembangkan keterampilan motorik, pengetahuan, dan perilaku hidup sehat 
dan aktif, sikap sportif, dan kecerdasanemosi. Lingkungan belajar diatur secara seksama untuk meningkatkan pertumbuhaan dan perkembangan seluruh ranah, jasmani, psikomotor, kognitif.

Menurut Syamsudin (2001: 3) pendidikan jasmani adalah proses proses pendidikan melalui penyediaan pengalaman belajar kepada anak berupa aktivitas jasmani bermain dan berolahraga yang direncanakan secara sistematis guna merangsang pertumbuhan dan perkembangan fisik, keterampilan motorik keterampilan berpikir, emosional, sosial dan moral. Melalui pembelajaran pendidikan jasmani, peserta didik akan memperoleh pengalaman yang eratkaitannya dengan pribadi yang menyenangkan, kreatif, inovatif, keterampilan gerak, kesegaran jasmani, pola hidup sehat pengetahuan dan pemahaman terhadap gerak manusia, juga akan membentuk kepribadian yang positif (Syamsudin, 2011: $4)$.

Perencanaan pendidikan jasmani harus dilakukan dengan seksama agar memenuhi perkembangan, pertumbuhan, dan kebutuhan dari setiap anak. Pendidikan jasmani ditunjukan untuk mengembangkan kemampuan psikomotorik, kognitif, dan afektif peserta didik.

Pada tahap pendidikan dini, sebaiknya anak disiapkan menghadapi perkembangan di masa depan untuk mendapatkan pembelajaran dan menjadi sumberdaya yang berkualitas. Ilmu pengetahuan yang dapat diterapkan pada kehidupan sehari-hari.

Model-model pembelajaran pendidikan jasmani didasarkan pada efektivitas pengelolaan pembelajaran dan mengasumsikan bahwa keberhasilan pencapaian tujuan pendidikan atas dasar pemilihan model yang tepat. Salah satu tujuan pembelajaran pendidikan jasmani yang akan dicapai adalah menjadikan fisik bugar. Model pendidikan edukatif bebasis jasmaniyang kita terapkan memiliki kelebihan memhuat anak lebih tertarik karena menggunakan cara yang edukatif, karena menumbuhkan rasa solidaritas yang tinggi dan menambah pengetahuan mereka tentang pentingnya jasmani.

Model edukatif berbasis jasmani adalah model pendidikan jasmani untuk anak usia dini yang memperhatikan aspek perkembangan kemampuan kognitif, 
afektif, dan psikomotor anak usia dini dalam mempersiapkan diri menuju kecerdasan emosional. Salah satu upaya pemanfaatan aktivitas jasmani dalam proses pengasuhan dan pengembangan siswa SD dengan mengembangkan Model AktivitasJasmani yang Edukatif dan Atraktif. Model ini merupakan model pembelajaran yang memanfaatkan aktivitas jasmani sebagai wahana pembelajaran dalam bingkai pendekatan tematik

Orang yang dapat menikmati hidup dan kehidupannya serta aktifitas fisik tanpa mengalami kelelahan yang berartihanya orang yang memiliki kebugaran fisik yang baik (physical Fitness). Seseorang yang memiliki kebugaran fisik dipandang dari aspek fisiologis terbagi ke dalam dua komponen yaitu kebugaran yang berhubungan dengan kesehatan dan kebugaran yang berhubungan dengan keterampilan.

Menurut Aulina (2013), penting bagi anak usia dini untuk berinteraksi dengan teman sebayanya untuk menimbulkan komunikasi yang intensif antar anak. Pada proses sosialisasi ini sangat penting dalam membentuk karakter anak sehingga di masa depan anak akan memiliki rasa saling memiliki. Hal tersebut penting dalam konteks pembangunan nasional karena untuk membentuk peradaban bangsa yang unggul. Tetapi, dalam realita yang terjadi, banyak orangtua yang belum mampu mengoptimalkan potensi anak, karena pada umumnya kegiatan yang orangtua berikan bersifat menjaga secara fisik serta memberikan asupan gizi yang dibutuhkan tetapi kurang dalam memberikan stimulasi edukasi.

Peran orang tua diperlukan untuk memberikan kesempatan kepada anak untuk melakukan edukasi pendidikan jasmani, sehingga anak tidak hanya mendapat teori atau konsep tetapi juga belajar komunikasi dan sosialisasi dalam olahraga.

Mengacu pada penelitian sebelumnya yang telah dilakukan oleh Mahardhika, Betty, Jusuf, \& Priyambada (2018), orangtua berperan penting dalam memberikan motivasi berprestasi anak-anaknya yang tengah menempuh Pendidikan SKOI Kalimantan Timur dalam bidang Pendidikan jasmani. Sementara itu, penelitian Edukatif \& Alam, (2018), menemukan hasil melalui 
model pembelajaran yang edukatif berbasis alam, dapat merevitalisasi pendidikan jasmani untuk anak usia dini, sehinga mereka kecerdasan kognitif, afektif dan psikomotorik mereka dapat berkembang. Dan penelitian lainnya yang dilakukan oleh Kharisma, (2018) menemukan hasil Pendidikan jasmani kepada anak sekolah dasar berpengaruh terhadap keterampilan motorik anak.

Berdasarkan temuan dari penelitian sebelumnya di atas, maka peneliti tertarik melakukan penelitian mengenai penerapan model edukatif berbasis Pendidikan jasmani untuk anak usia 8-12 tahun di SSB Garuda Indoneisa. Tujuan penelitian ini adalah memberikan edukasi jasmani pada anak usia dini disekitar usia 8-12 tahun dengan memberikan permainan edukatif berbasis pendidikan jasmani. Penelitian ini ingin mencari tahu bagaimana aspek pembelajaran Pendidikan jasmani yang bisa dilakukan di dalam lingkungan sekolah dan SSB. Manfaat dari penelitian, diharapkan dapat memberi kontribusi pada pembelajaran Pendidikan jasmani yang lebih berkualitas di sekolah dan di luar sekolah.

\section{METODE}

Penelitian ini menggunakan metodologi penelitian kualitatif dengan format deskriptif memiliki tujuan untuk memberi penjelasan, memberi ringkasan dari berbagai situasi. Peneliti menggunakan teknik observasi dan wawancara untuk mengumpulkan data penelitian.

Menurut Bungin (2015), ada beberapa metode pengumpulan data dalam penelitian kualitatif yang paling sering digunakan, salah satunya adalah wawancara. Wawancara di dalam pengumpulan data penelitian, adalah percakapan yang bertujuan dengan mendapatkan informasi perorangan. Dengan demikian, wawancara adalah suatu percakapan yang diarahkan pada suatu masalah tertentu, dan merupakan proses tanya jawab lisan dua orang atau lebih, yang berhadap-hadapan secara fisik.

Penelitian kualitatif adalah penelitian yang digunakan untuk meneliti pada kondisi objek alamiah, dimana peneliti merupakan instrumen kunci (Sugiyono, 2012). Menurut Moleong (2015), penelitian kualitatif adalah penelitian yang bermaksud untuk memahami fenomena tentang apa yang dialami oleh subjek 
penelitian misalnya perilaku, persepsi, motivasi, tindakan, dll secara holistic, dan dengan cara deskripsi dalam bentuk kata-kata dan bahasa, pada suatu konteks khusus yang alamiah dan dengan memanfaatkan berbagai metode alamiah. Secara umum dapat digunakan untuk penelitian tentang kehidupan masyarakat, sejarah, tingkah laku, fungsionalisasi organisasi, aktivitias sosial, dan lain-lain. Salah satu alasan menggunakan pendekatan kualitatif adalah pengalaman para peneliti dimana metode ini dapat digunakan untuk menemukan dan memahami apa yang tersembunyi dibalik fenomena yang kadangkala merupakan sesuatu yang sulit untuk dipahami secara memuaskan.

Istilah penelitian kualitatif menurut Kirk \& Miller dalam Herdiansyah (2010), pada mulanya yang bersumber pada pengamatan kualitatif yang dibedakan dengan penelitian kuantitatif. Lalu mereka mendefinisikan bahwa metodologi kualitatif adalah suatu tradisi dalam ilmu pengetahuan sosial yang secara fundamental bergantung pada pengamatan pada manusia dalam lingkungannya sendiri dan berhubungan dengan orang orang tersebut dalam bahasanya dan dalam peristilahannya.

Penelitian dengan pendekatan kualitatif dapat dibedakan menjadi tujuh tipe utama, yaitu: phenomenology, ethnography, action research, biography, grounded theory, design and development research, and case studi and field research (Jonhson dan Wichern, 2005: 8).

Penelitian tindakan (action research) adalah suatu proses yang dirancang untuk memberdayakan semua partisipan dalam proses (siswa, guru, dan peserta didik lainnya) dengan maksud untuk meningkatkan praktik yang diselenggarakan di dalam pengalaman pendidikan. Penelitian tindakan bertujuan untuk memberikan konstribusi kepada kepedulian praktis dari orang dalam situasi problematic secara langsung dan untuk tujuan lebih lanjut dari ilmu sosial secara serempak (Sugiyono, 2012). Faktor atau dimensi yang digunakan bersifat eksploratif atau menguji dan juga memperhalus teori dan konsep yang telahada. Pertanyaan wawancara disini adalah seputar pentingnya pendidikan olahraga/jasmani terhadap anak-anak usia 7-12 tahun. 
Teknik analisis data yang digunakan dalam penelitian ini adalah teknik deskriptif yaitu data diolah dan dianalisis dengan langkah-langkah sebagai berikut: (1) Setelah ditanyakan lima buah pertanyaan dari daftar pertanyaan wawancara, kemudian akan kita catat jawaban dari setiap narasumber, (2) Beradsarkan setiap jawaban informan yang sudah di catat dilakukan penelitian, (3) penyocokan atau pencarian bentuk edukatif apa yang cocok untuk digunakan dalam pendidikan jasmani, dan (4) hasil wawancara akan disimpulkan atau dibaca secara manual untuk memasukan data di hasil penelitian.

Setelah memperoleh data di lapangan, kemudian hasilnya akan dilakukan disajikan menggunakan data berupa naratif. Kegiatan ini harus dikuasai dengan benar, sebab data yang telah disajikan secara sistematis. Hasil wawancara akan dimanfaatkan untuk menginformasikan tentang temuan penelitian. Setelah penyajian data dilakukan, kemudian dilakukan penarikan kesimpulan.

\section{HASIL DAN PEMBAHASAN}

Peneliti telah melakukan obeservasi dan wawancara mendalam, tentang pentingnya pendidikan jasmani kepada anak usia 8 - 12 tahun di Sekolah Sepak Bola Garuda Indonesia. Observasi dan wawancara tersebut dilakukan kepada 6 orang responen, yaitu Daffa (12 th), Rahman (8 th), Fatur (9 th), Fandi (9th), Ghifari (10 th) dan juga Hilmi (9 th). Menurut ke enam informan, faktor yang membuat mereka menyukai olahraga, terutama speak bola, adalah mereka merasa senang dan merasa adanya keseruan dalam melakukan olahraga speak bola.

Keenam informan juga mengatakan bahwa sekolah mereka juga sudah menerapkan pendidikan jasmani di pelajaran olahraga, kepada anak-anak berusia 8-12 tahun. Contohnya adalah ada pelajaran pengolahan jasmani, yang melakukan penerapan pelajaran model edukatif jasmani, berupa pembelajaran yang dilakukan di luar kelas dan menerapkan konsep edukatif jasmani seperti senam, dan game interaktif lainnya. Selain itu, keenam informan juga mengatakan bahwa mereka lebih bersemangat dan merasa pelajaran lebih menyenangkan, jika guru menerapkan sistem model edukatif berbasis jasmani. 
Keenam responden mengatakan, 'menyenangkan' dan 'seru', karena menurut mereka, jika sekolah menerapkan sistem pembelajaran seperti model edukatif berbasis jasmani, selain membantu pembelajaran anak di sekolah, juga membuat mereka lebih sehat karena aktivitas yang mereka lakukan. Yang terakhir adalah dari informan kami mengatakan bahwa olahraga dan kegiatan jasmani yang membuat mereka semangat dalam melakukan pelajaran, adalah suatu kegiatan yang berbasis di luar kelas dan interaktif.

Berdasarkan data yang telah peneliti kumpulkan berdasarkan 6 orang informan di atas, bisa disimpulkan bahwa informan memiliki antusiasme dan sangat senang akan pembelajaran jasmani. Hal tersebut dikarenakan, informan yang usianya yang masih dini, sudah mengetahui pentingnya dalam mengolah jasmani dan juga mempelajarinya. Informan menyakini bahwa berolahraga dengan model edukatif berbasis jasmani, selain dapat membantu mengontrol emosi dalam melakukan kerja tim, mereka juga dapat mengembangkan emosi mereka. Keenam informan menyatakan bahwa sekolah mereka, sudah sadar mengenai pentingnya pengolahan jasmani karena sekolah mereka memiliki pelajaran dan penerapan jasmani yang berkonsep mengembangkan dan membantu mempelajari pelajaran yang susah dimengerti anak-anak, dengan memakai cara dan konsep interaktif di setiap harinya.

Informan kami juga mengatakan bahwa mereka lebih menyukai dan lebih menginginkan pembelajaran di luar kelas dan mengaplikasikan konsep interaktif jasmani. Dan yang terakhir yang bisa disimpulkan bahwa mereka akan lebih semangat belajar dengan konsep jasmani dengan model edukatif berbasis jasmani.

Dari hasil penelitian ini memperkuat penelitian dari Gallahue dan Donnelly (2003: 10) yang menyatakan bahwa pendidikan melalui aktivitas jasmani pada anak, di jenjang pendidikan dasar, dapat membantu pengontrolan pengembangan emosional, membantu pertumbuhan dan perkembangan serta membantu persiapan untuk memasuki pada jenjang pendidikan formal, pengembangan kesehatan, kebugaran dan pengembangan kinestetik. 


\section{SIMPULAN}

Dari hasil penelitian dan wawancara yang sudah dilakukan pada keenam informan anak yang gemar berolahraga bermain bola di atas, dapat disimpulkan bahwa bila model edukatif berbasis jasmani yang diterapkan pada anak usia dini, akan menghasilkan hal yang lebih baik dalam fisik, kecerdasan, dan mengendalikan emosi anak. Dari hasil penelitian, ditemukan bahwa anak-anak yang sering berolahraga pada saat usia dini, lebih mudah dalam belajar dan berteman dibandingkan dengan yang tidak. Dari hasil wawancara di atas, juga ditemukan, anak-anak yang senang beraktivitas diluar seperti olahraga juga lebih mudah bersosialisasi, jika dibandingkan dengan anak yang tidak. Keenam informan juga mengatakan bahwa mereka lebih senang beraktivitas diluar dan menyukai olahraga dalam pelajaran sekolahnya, karena mereka mengerti manfaat dari olahraga. Untuk itu, sebagai saran, lebih baik jika sekolah menyediakan aktivitas luar ruangan yang memadai untuk mengedukasi anak-anak, tidak hanya untuk menjaga kesehatan fisik anak, namun juga mental anak dalam pertumbuhannya.

\section{DAFTAR PUSTAKA}

Aulina, C., N. (2013). Penanaman disiplin pada anak usia dini. Jurnal Pedagogia: Jurnal Pendidikan Universitas Muhammadiyah Sidoarjo, 2(1), (Online), (ojs.umsida.ac.id/index.php/pedagogia/article/viewFile/45/51, diakses 03 Juni 2019).

Bungin, B. (2015). Metode penelitian kuantitatif. Jakarta: Prenada Media.

Edukatif, B., \& Alam, B. (2018). Jurnal pendidikan jasmani dan olahraga, 3(1), 41-51.

Gallahue, D. L., \& Donnelly, F. C. (2003). Developmental Physical Education for All Children (4th ed). Champaign, IL: Human Kinetics.

Herdiansyah, H. (2010). Metodologi penelitian kuantitatif. Jakarta: Salemba Humanika.

Johnson, R. A., \& Wichern, D. W. (2007). Applied multivariate statistical analysis 6th edition. United States of America: Pearson Education Inc.

Kharisma, V., A. (2018). pengaruh media pembelajaran edukatif dalam pembelajaran pendidikan jasmani terhadap keterampilan motorik dasar siswa sekolah dasar. journal of teaching physical education in elementary school 2(1), 53-59.

Mahardhika, N., A., Betty, J., Jusuf, K., \& Priyambada, G. (2018). Dukungan orangtua terhadap motivasi berprestasi siswa skoi kalimantan timur dalam 
mengikuti pembelajaran pendidikan jasmani parental support for the achievement motivation of skoi students in east kalimantan in attending physical education learning, 14(2), 62-68.

Moleong, L., J. (2015). Metodologi penelitian kualitatif. Bandung: Remaja Rosdakarya.

Samsudin. (2008). Pembelajaran motorik di taman kanak-kanak. Jakarta: Prenada Media Group.

Sugiyono. (2012). Metode penelitian kuantitatif, kualitatif dan $R \& D$. Edisi pertama. Bandung. PT. Alfabeta.

Syamsudin. (2011). Buku ajar farmakoterapi kardiovaskular dan renal. Jakarta: Penerbit Salemba Medika. 